\title{
DynamicSainT
}

\author{
Jilid. V No. 1., April 2020
}

\section{ARUS LALU LINTAS, KAPASITAS DAN TINGKAT PELAYANAN RUAS JALAN DALAM KOTA RANTEPAO}

\author{
Abdias Tandi Arrang ${ }^{*}$, Parea Rusan Rangan² \\ Program Studi Teknik Sipil, Fakultas Teknik, Universitas Kristen Indonesia Toraja. \\ Jl. Nusantara No. 12,Makale, Tana Toraja, Sulawesi Selatan \\ 1*diastandy@gmail.com, ${ }^{2}$ pareausanrangan68@gmail.com
}

\begin{abstract}
ABSTRAK
Transportasi mempunyai hubungan yang erat dengan pembangunan. Lancarnya arus lalu lintas akan mendukung arus distribusi barang serta meningkatkan mobilitas masyarkat dalam usaha pemenuhan kebutuhan. Salah satu parameter yang penting untuk diketahui dalam perencanaan lalu lintas perkotaan adalah kapasitas jalan. Kapasitas adalah daya tampung maksimum jalan. Tingkat pelayanan jalan akan menurun seiring dengan meningkatnya rasio volume per kapasitas jalan. Penelitian ini dilakukan dengan survey kondisi geometrik, konfigurasi lajur, hambatan samping dan jumlah kendaraan dalam berbagai jenis pada beberapa ruas jalan dalam Kota Rantepao. Data kemudian diolah berdasarkan MKJI 1997 sehingga diperoleh kapasitas masingmasing jalan, sementara untuk tingkat pelayanan jalan diperoleh dengan membandingkan kondisi arus lalu-lintas dengan kapasitas jalan. Hasil penelitian menunjukkan bahwa arus maksimum tertinggi terjadi di Jl. Pongtiku yaitu sebesar 1.423,4 SMP/Jam pada pagi hari Pukul 07.00 - 08.00. Sementara kapasitas ruas Jl. Mongsidi sebesar 2.225,65 SMP/Jam; Jl. Pongtiku 2.612,71 SMP/Jam; Jl. A. Mappanyuki 1.355,85 SMP/Jam per lajur; Jl. Ahmad Yani 1.333,86 SMP/Jam per lajur; dan Jl. Poros Rantepao-Bolu sebesar 2.534,33 SMP/Jam. Ratio V/C saat kondisi arus maksimum untuk Jl. Mongsidi 0,36; Jl. Pongtiku 0,54; Jl. A. Mappanyuki arah selatan dan utara masin-masing 0,35 dan 0,26;Jl. A. Yani arah utara dan selatan 0,51 dan 0,52; sementara Jl. Poros Rantepao - Bolu 0,42; Semuanya dalam tingkat pelayanan tipe B.
\end{abstract}

Kata Kunci: arus lalu lintas, kapasitas, tingkat pelayanan.

\section{PENDAHULUAN}

Kinerja jalan yang baik akan memberikan layanan yang optimum kepada penggunanya. Dalam sistem transportasi standar mutu pelayanan adalah kecepatan, keselamatan, kenyamanan, kelancaran, keandalan, ekonomis dan terjangkau (Miro 2012).

Kelancaran lalu lintas pada suatu ruas jalan sangat ditentukan oleh kapasitas jalan tersebut. TRB (2000) menyatakan bahwa kapasitas dari suatu fasilitas adalah jumlah per jam maksimum di mana orang/kendaraan diperkirakan akan dapat melintasi sebuah titik atau suatu ruas jalan selama periode waktu tertentu pada kondisi jalan, lalu-lintas, pengendalian biasa (Khisty 2005). Kondisi tersebut adalah geometrik, konfigurasi arus lalu-lintas, hambatan samping dan lain-lain.
Semakin lancar lalu lintas yang artinya kapasitas maksimum jalan belum tercapai maka tingkat pelayanan jalan semakin baik. Namun sebaliknya arus lalu lintas yang tinggi bahkan melewati kapasitas jalan maka tingkat pelayanan jalan akan rendah.

Kota Rantepao merupakan pusat pemerintahan dan pusat perekonomian Kabupaten Toraja Utara. Aktifitas pelayanan pemerintahan dan perekonomian kian hari kian meningkat. Peningkatan arus lalu lintas juga akan semakin tinggi dengan selesainya bandar udara baru oleh karena Tana Toraja dan Toraja Utara adalah salah satu tujuan wisata nasional dan internasional (Rangan 2014). Adapun tujuan peneltian ini terhadap ruas jalan dalam Kota Rantepao ini adalah: 1) Untuk mengetahui fluktuasi dan arus maksimum lalu lintas. 2) Untuk mengetahui 


\section{DynamicSainT}

Jilid. V No. 1., April 2020

kapasitas ruas jalan. 3) Untuk mengetahui tingkat pelayanan (Level of Service, LOS) ruas jalan pada kondisi arus maksimum.

Karena terbatasnya waktu dan sumber daya yang ada maka batasan masalah dari penelitian ini adalah : 1) Survey arus dilakukan hanya pada ruas Jl. Monginsidi, Jl. Ratulangi, Jl. Pongtiku, Jl. Mappanyuki, Jl. A. Yani, Jl. Poros Bolu - R. Pao. 2) Survey dilakukan satu hari dari pukul $06.00-18.00$.

\section{KAJIAN PUSTAKA}

\subsection{Arus Lalu Lintas}

Untuk menggambarkan kondisi lalu lintas secara terukur dikenal beberapa variabel antara lain arus / volume, kecepatan dan kepadatan.

Definisi arus / volume (V) lalu lintas adalah jumlah kendaraan dalam satuan mobil penumpang (SMP) yang melalui suatu potongan melintang jalan dalam satuan waktu tertentu (Putranto 2016).

\subsection{Klasifikasi Kendaraan}

Salah satu ciri negara berkembang seperti Indonesia adalah bercampurnya berbagai jenis kendaraan dalam ruang jalan yang sama (Putranto 2016). Kendaraan yang melintas di jalan sangat beragam untuk itu diperlukan adanya klasifikasi kendaraan untuk memudahkan dalam analisis arus lalu lintas. Klasfikasi kendaraan dipengaruhi oleh dimensi kendaraan, konfigurasi sumbu atau gandar dan kemampuan kinerja kendaraan tersebut. Klasifikasi kendaraan menurut MKJI 1997 (Ditjen Bina Marga 1997) dapat dilihat pada Tabel 1.

\subsection{Satuan Mobil Penumpang}

Satuan mobil penumpang (SMP) merupakan suatu ukuran yang menunjukkan ruang jalan yang dipergunakan oleh suatu jenis kendaraan serta kemampuan manuver kendaraan tersebut (Putranto 2016).

Manual Kapasitas Jalan Indonesia (Ditjen Bina Marga 1997), memberikan nilai

1 SMP untuk mobil penumpang (kendaraan ringan), dan disebut nilai EMP (ekivalen mobil penumpang) sebesar 1. Nilai EMP untuk tiap jenis kendaraa dipengaruhi oleh beberapa hal, antara lain: konfigurasi lajur, jumlah kendaraan, jenis alinamen dan lebar jalur. Nilai ekivalen mobil penumpang (EMP) untuk jalan dalam kota dapat dilihat dalam Tabel 2 dan Tabel 3.

Tabel 1. Ekivalensi Klasifikasi Kendaraan menurut MKJI (Ditjen Bina Marga 1997)

\begin{tabular}{|c|c|c|}
\hline Jalan Kota & $\begin{array}{c}\text { Jalan } \\
\text { Antar Kota }\end{array}$ & Keterangan \\
\hline \multicolumn{2}{|c|}{ Kendaraan Ringan } & $\begin{array}{l}\text { Kendaraan bermotor roda } 4 \\
\text { berjarak gandar 2-3 m, } \\
\text { meliputi kendaraan } \\
\text { penumpang, oplet, bus mikro, } \\
\text { pick up dan truk mikro pada } \\
\text { sistem klasifikasi Bina Marga }\end{array}$ \\
\hline \multirow{3}{*}{$\begin{array}{l}\text { Kendaraan } \\
\text { Berat }\end{array}$} & $\begin{array}{l}\text { Medium } \\
\text { Heavy } \\
\text { Vehicle }\end{array}$ & $\begin{array}{l}\text { Kendaran bermotor berjarak } \\
\text { gandar 3,5-5 m, meliputi bus } \\
\text { kecil truk } 2 \text { gandar beroda } 6 \\
\text { pada sistem klasifikasi Bina } \\
\text { Marga }\end{array}$ \\
\hline & Truk Besar & $\begin{array}{l}\text { Truk } 3 \text { gandar dan truk } \\
\text { gandeng dengan jarak gandar } \\
\text { pertama ke gandar ke } 2<3,5 \\
\text { m }\end{array}$ \\
\hline & Bus Besar & $\begin{array}{l}\text { Bus } 2 \text { atau } 3 \text { gandar berjarak } \\
\text { antar gandar 5-6 m. }\end{array}$ \\
\hline \multicolumn{2}{|c|}{ Sepeda Motor } & $\begin{array}{l}\text { Sepeda motor beroda } 2 \text { atau } \\
3 \text {, meliputi sepeda motor dan } \\
\text { kendaraan roda } 3 \text { pada sistem } \\
\text { klasifikas Bina Marga }\end{array}$ \\
\hline Kendaraan & dak Bermotor & $\begin{array}{l}\text { Kendaraan beroda bertenaga } \\
\text { manusia atau hewan, } \\
\text { termasuk sepeda becak, } \\
\text { kereta kuda dan kereta } \\
\text { dorong pada sistem } \\
\text { klasifikasi Bina Marga. }\end{array}$ \\
\hline
\end{tabular}




\section{DynamicSainT}

Jilid. V No. 1., April 2020

Tabel 2. Nilai EMP Jalan Kota Tak Terbagi menurut MKJI (Ditjen Bina Marga 1997)

\begin{tabular}{|c|c|c|c|c|}
\hline \multirow{4}{*}{$\begin{array}{c}\text { Jenis Jalan: } \\
\text { Jalan Tak } \\
\text { Terbagi }\end{array}$} & \multirow{4}{*}{$\begin{array}{c}\text { Arus LL } \\
\text { Total } 2 \text { Arah } \\
\text { (Kend/Jam) }\end{array}$} & \multicolumn{3}{|c|}{ EMP } \\
\hline & & \multirow{3}{*}{$\mathbf{K B}$} & \multicolumn{2}{|c|}{ SM } \\
\hline & & & \multicolumn{2}{|c|}{$\begin{array}{c}\text { Lebar } \\
\text { Jalur (m) }\end{array}$} \\
\hline & & & $\leq 6$ & $>6$ \\
\hline \multirow{2}{*}{ 2/2 UD } & $<1800$ & 1,3 & 0,5 & 0,4 \\
\hline & $\geq 1800$ & 1,2 & 0,35 & 0,25 \\
\hline \multirow{2}{*}{ 4/2 UD } & $<3700$ & 1,3 & \multicolumn{2}{|c|}{0,4} \\
\hline & $\geq 3700$ & 1,2 & \multicolumn{2}{|c|}{0,25} \\
\hline
\end{tabular}

Tabel 3. Nilai EMP Jalan Kota Terbagi menurut MKJI (Ditjen Bina Marga 1997)

\begin{tabular}{|c|c|c|c|}
\hline \multirow{2}{*}{$\begin{array}{c}\text { Jenis Jalan : } \\
\text { Jalan } 1 \text { Arah dan } \\
\text { Jalan Terbagi }\end{array}$} & \multirow{2}{*}{$\begin{array}{c}\text { Arus LL } \\
\text { Total } 2 \text { Arah } \\
\text { (Kend/Jam) }\end{array}$} & \multicolumn{2}{|c|}{ EMP } \\
\hline & & KB & SM \\
\hline $2 / 1$ & $<1050$ & 1,3 & 0,4 \\
\hline $4 / 2 \mathrm{D}$ & $\geq 1050$ & 1,2 & 0,25 \\
\hline $3 / 1$ & $<1100$ & 1,3 & 0,4 \\
\hline $6 / 2 \mathrm{D}$ & $\geq 1100$ & 1,2 & 0,25 \\
\hline
\end{tabular}

\subsection{Kapasitas Jalan}

Kapasitas jalan dalam dalam MKJI (Ditjen Bina Marga 1997) seperti dalam Persamaan (1).

\section{$\mathrm{C}=\mathrm{C}_{\mathrm{o}} \times \mathrm{F}_{\mathrm{CW}} \times \mathrm{FC}_{\mathrm{SP}} \times \mathrm{FC}_{\mathrm{SF}} \times \mathrm{FC}_{\mathrm{CS}}$}

Dimana C adalah kapasitas dalam SMP/jam, Co adalah kapasitas dasar dalam SMP/jam, $\mathrm{F}_{\mathrm{CW}}$ adalah faktor pengaruh lebar lajur, $\mathrm{FC}_{\mathrm{SP}}$ adalah faktor pengaruh distribusi arah, $\mathrm{FC}_{\mathrm{SF}}$ adalah faktor pengaruh hambatan samping dan $\mathrm{FC}_{\mathrm{CS}}$ adalah faktor pengaruh ukuran kota,

Penentuan nilai kapasitas dasar jalan kota $\left(\mathrm{C}_{\mathrm{O}}\right)$ dapat dilihat pada Tabel 4, faktor pengaruh lebar lajur $\left(\mathrm{F}_{\mathrm{CW}}\right)$ Tabel 5, faktor pengaruh distribusi arah $\left(\mathrm{FC}_{\mathrm{SP}}\right)$ Tabel 6.
Tabel 4. Kapasitas Dasar Jalan Kota menurut MKJI (Ditjen Bina Marga 1997)

\begin{tabular}{lcc}
\hline \multicolumn{1}{c}{ Tipe Jalan } & $\begin{array}{c}\text { Kapasitas } \\
\text { Dasar } \\
\text { (SMP/jam) }\end{array}$ & Keterangan \\
\hline $\begin{array}{l}4 \text { lajur } \\
\text { bermedian atau } \\
\text { jalan 1 arah }\end{array}$ & 1.650 & Per Lajur \\
\hline $\begin{array}{l}\text { 4 lajur tak } \\
\text { bermedian }\end{array}$ & 1.500 & Per Lajur \\
\hline $\begin{array}{l}\text { 2 lajur tak } \\
\text { bermedian }\end{array}$ & 2.900 & $\begin{array}{c}\text { Total di kedua } \\
\text { lajur }\end{array}$ \\
\hline
\end{tabular}

Tabel 5. Faktor Pengaruh Lebar Lajur $\left(\mathrm{FC}_{\mathrm{W}}\right)$ menurut MKJI (Ditjen Bina Marga 1997)

\begin{tabular}{|c|c|c|}
\hline Tipe Jalan & $\begin{array}{l}\text { ebar Lajur } \\
\text { LL efektif } \\
\text { (m) }\end{array}$ & $\mathbf{F C w}$ \\
\hline \multirow{6}{*}{$\begin{array}{l}4 \text { lajur bermedian } \\
\text { atau jalan satu arah }\end{array}$} & Per lajur & \\
\hline & 3,00 & 0,92 \\
\hline & 3,25 & 0,96 \\
\hline & 3,50 & 1,00 \\
\hline & 3,75 & 1,04 \\
\hline & 4,00 & 1,08 \\
\hline \multirow{6}{*}{$\begin{array}{l}4 \text { lajur tak } \\
\text { bermedian }\end{array}$} & Per lajur & \\
\hline & 3,00 & 0,91 \\
\hline & 3,25 & 0,95 \\
\hline & 3,50 & 1,00 \\
\hline & 3,75 & 1,05 \\
\hline & 4,00 & 1,09 \\
\hline \multirow{8}{*}{$\begin{array}{l}2 \text { lajur tak } \\
\text { bermedian }\end{array}$} & Total & \\
\hline & 5 & 0,69 \\
\hline & 6 & 0,91 \\
\hline & 7 & 1,00 \\
\hline & 8 & 1,08 \\
\hline & 9 & 1,15 \\
\hline & 10 & 1,21 \\
\hline & 11 & 1,27 \\
\hline
\end{tabular}

Tabel 6. Faktor Pengaruh Distribusi Arah ( $\left.\mathrm{FC}_{\mathrm{SP}}\right)$ menurut MKJI (Ditjen Bina Marga 1997)

\begin{tabular}{lllllll}
\hline $\begin{array}{l}\text { Split Arah } \\
\text { \%-\% }\end{array}$ & $\begin{array}{l}\mathbf{5 0 -} \\
\mathbf{5 0}\end{array}$ & $\begin{array}{l}\mathbf{5 5}- \\
\mathbf{4 5}\end{array}$ & $\begin{array}{l}\mathbf{6 0 -} \\
\mathbf{4 0}\end{array}$ & $\begin{array}{l}\mathbf{6 5}- \\
\mathbf{3 5}\end{array}$ & $\begin{array}{l}\mathbf{7 0 -} \\
\mathbf{3 0}\end{array}$ \\
\hline \multirow{2}{*}{$\mathrm{FC}$} & $2 / 2$ & 1,00 & 0,970 & 0,94 & 0,910 & 0,88 \\
\cline { 2 - 7 } & $4 / 2$ & 1,00 & 0,975 & 0,95 & 0,925 & 0,90 \\
\hline
\end{tabular}

Sementara koefisien untuk faktor pengaruh hambatan samping $\left(\mathrm{FC}_{\mathrm{SF}}\right)$ dapat dilihat pada Tabel 7 


\section{DynamicSainT}

Jilid. V No. 1., April 2020

Tabel 7. Faktor Pengaruh Hambatan Samping $\left(\mathrm{FC}_{\mathrm{SF}}\right)$ menurut MKJI ( (Ditjen Bina Marga 1997)

a. Jalan Berbahu

\begin{tabular}{|c|c|c|c|c|c|}
\hline \multirow{3}{*}{$\begin{array}{l}\text { Tipe } \\
\text { Jalan }\end{array}$} & \multirow{3}{*}{$\begin{array}{l}\text { Hambatan } \\
\text { Samping }\end{array}$} & \multicolumn{4}{|c|}{ Lebar Bahu \& $\mathbf{F C}_{\mathrm{SF}}$} \\
\hline & & \multicolumn{4}{|c|}{ Rata-rata lebar bahu (m) } \\
\hline & & $\leq 0,5$ & 1,0 & 1,5 & $\geq 2,0$ \\
\hline \multirow[t]{5}{*}{$4 / 2 \mathrm{D}$} & Sangat Rendah & 0,96 & 0,98 & 1,01 & 1,03 \\
\hline & Rendah & 0,94 & 0,97 & 1,00 & 1,02 \\
\hline & Sedang & 0,92 & 0,95 & 0,98 & 1,00 \\
\hline & Tinggi & 0,88 & 0,92 & 0,95 & 0,98 \\
\hline & Sangat Tinggi & 0,84 & 0,88 & 0,92 & 0,96 \\
\hline \multirow{5}{*}{$\begin{array}{l}4 / 2 \\
\text { UD }\end{array}$} & Sangat Rendah & 0,96 & 0,99 & 1,01 & 1,03 \\
\hline & Rendah & 0,94 & 0,97 & 1,00 & 1,02 \\
\hline & Sedang & 0,92 & 0,95 & 0,98 & 1,00 \\
\hline & Tinggi & 0,87 & 0,91 & 0,94 & 0,98 \\
\hline & Sangat Tinggi & 0,80 & 0,86 & 0,90 & 0,95 \\
\hline \multirow{5}{*}{$\begin{array}{c}2 / 2 \\
\text { UD } \\
\text { /jalan } \\
\text { satu } \\
\text { arah }\end{array}$} & Sangat Rendah & 0,94 & 0,96 & 0,99 & 1,01 \\
\hline & Rendah & 0,92 & 0,94 & 0,97 & 1,00 \\
\hline & Sedang & 0,89 & 0,92 & 0,95 & 0,98 \\
\hline & Tinggi & 0,82 & 0,86 & 0,90 & 0,95 \\
\hline & Sangat Tinggi & 0,73 & 0,79 & 0,85 & 0,91 \\
\hline
\end{tabular}

b. Jalan berkerb

\begin{tabular}{|c|c|c|c|c|c|}
\hline \multirow{3}{*}{$\begin{array}{c}\text { Tipe } \\
\text { Jalan }\end{array}$} & \multirow{3}{*}{$\begin{array}{c}\text { Hambatan } \\
\text { Samping }\end{array}$} & \multirow{2}{*}{\multicolumn{4}{|c|}{$\begin{array}{c}\text { Jarak kerb-penghalang \& } \text { FC }_{\mathrm{SF}} \\
\text { Jarak kerb-penghalang }(\mathrm{m})\end{array}$}} \\
\hline & & & & & \\
\hline & & $\leq 0,5$ & 1,0 & 1,5 & $\geq 2,0$ \\
\hline \multirow[t]{5}{*}{$4 / 2 \mathrm{D}$} & Sangat Rendah & 0,95 & 0,97 & 0,99 & 1,01 \\
\hline & Rendah & 0,94 & 0,96 & 0,98 & 1,00 \\
\hline & Sedang & 0,91 & 0,93 & 0,95 & 0,98 \\
\hline & Tinggi & 0,86 & 0,89 & 0,92 & 0,95 \\
\hline & Sangat Tinggi & 0,81 & 0,85 & 0,88 & 0,92 \\
\hline \multirow[t]{5}{*}{$4 / 2$ UD } & Sangat Rendah & 0,95 & 0,97 & 0,99 & 1,01 \\
\hline & Rendah & 0,93 & 0,95 & 0,97 & 1,00 \\
\hline & Sedang & 0,90 & 0,92 & 0,95 & 0,97 \\
\hline & Tinggi & 0,84 & 0,87 & 0,90 & 0,93 \\
\hline & Sangat Tinggi & 0,77 & 0,81 & 0,85 & 0,90 \\
\hline \multirow{5}{*}{$\begin{array}{c}2 / 2 \text { UD } \\
\text { /jalan } \\
\text { satu } \\
\text { arah }\end{array}$} & Sangat Rendah & 0,93 & 0,95 & 0,97 & 0,99 \\
\hline & Rendah & 0,90 & 0,92 & 0,95 & 0,97 \\
\hline & Sedang & 0,86 & 0,88 & 0,91 & 0,94 \\
\hline & Tinggi & 0,78 & 0,81 & 0,84 & 0,88 \\
\hline & Sangat Tinggi & 0,68 & 0,72 & 0,77 & 0,82 \\
\hline
\end{tabular}

Hambatan samping dipengaruhi oleh beberapa hal antara lain pejalan kaki, kendaraan berhenti atau parkir serta yang keluar dan masuk persil. Jenis kejadian hambatan samping dan faktor pembobotnya dapat dilihat dalam Tabel 8.

Tabel 8. Jenis Kejadian Hambatan Samping menurut MKJI (Ditjen Bina Marga 1997)

a. Penilaian besarnya hambatan samping

\begin{tabular}{lccccc}
\hline \multicolumn{1}{c}{$\begin{array}{c}\text { Jenis } \\
\text { Hambatan } \\
\text { Samping }\end{array}$} & \multicolumn{5}{c}{ Jumlah Hambatan Samping } \\
\cline { 2 - 6 } & SR & R & S & T & ST \\
\hline $\begin{array}{l}\text { Pejalan Kaki } \\
\text { (org/jam) }\end{array}$ & 0 & $0-80$ & $80-120$ & $120-220$ & $>200$ \\
\hline $\begin{array}{l}\text { Pejalan Kaki } \\
\text { menyeberang } \\
\text { (org/jam/km) }\end{array}$ & 0 & $0-200$ & $200-500$ & $500-1300$ & $>1300$ \\
\hline $\begin{array}{l}\text { Kendaraan } \\
\text { berhenti/parkir } \\
\text { (kend/jam/km) }\end{array}$ & 0 & $0-100$ & $100-300$ & $300-700$ & $>700$ \\
\hline $\begin{array}{l}\text { Kendaraan } \\
\text { keluar masuk } \\
\text { persil } \\
\text { (kenda/jam/km) }\end{array}$ & 0 & $0-200$ & $200-500$ & $500-800$ & $>800$ \\
\hline
\end{tabular}

b. Kegiatan di sekitar jalan

\begin{tabular}{lccccc}
\hline \multirow{2}{*}{$\begin{array}{l}\text { Komponen Hambatan } \\
\text { Samping }\end{array}$} & \multicolumn{6}{c}{ Kelas Hambatan Samping } \\
\cline { 2 - 6 } & SR & R & S & T & ST \\
\hline $\begin{array}{l}\text { Pergerakan Pejalan } \\
\text { Kaki }\end{array}$ & 0 & 1 & 2 & 4 & 7 \\
\hline $\begin{array}{l}\text { Kendaraan } \\
\text { Parkir/Berhenti di Sisi } \\
\text { Jalan }\end{array}$ & 0 & 1 & 3 & 6 & 9 \\
\hline $\begin{array}{l}\text { Kendaraan Keluar } \\
\text { Masuk Persil }\end{array}$ & 0 & 1 & 3 & 5 & 8 \\
\hline & & & & & \\
\hline
\end{tabular}

Nilai Total

Kelas Hambatan Samping

\begin{tabular}{cc}
\hline $0-1$ & Sangat Rendah (SR) \\
\hline $2-5$ & Rendah (R) \\
\hline $6-11$ & Sedang (S) \\
\hline $12-18$ & Tinggi (T) \\
\hline $19-24$ & Sangat Tinggi (ST) \\
\hline
\end{tabular}

Sementara untuk faktor pengaruh ukuran kota $\left(\mathrm{FC}_{\mathrm{CS}}\right)$ dapat dilihat pada Tabel 9. 


\section{DynamicSainT}

Jilid. V No. 1., April 2020

Tabel 9. Faktor Pengaruh Ukuran Kota $\left(\mathrm{FC}_{\mathrm{CS}}\right)$ menurut MKJI (Ditjen Bina Marga 1997)

\begin{tabular}{ccc}
\hline Ukuran Kota & $\begin{array}{c}\text { Jml Penduduk } \\
\text { (juta) }\end{array}$ & (FCCs) \\
\hline Sangat Kecil & $<0,1$ & 0,86 \\
\hline Kecil & $0,1-0,5$ & 0,90 \\
\hline Sedang & $0,5-1,0$ & 0,94 \\
\hline Besar & $1,0-3,0$ & 1,00 \\
\hline Sangat Besar & $>3,0$ & 1,04 \\
\hline
\end{tabular}

\subsection{Tingkat Pelayanan}

(Khisty 2005) menyebutkan bahwa tingkat pelayanan (level of service, LOS) adalah suatu ukuran kualitatif yang menjelaskan kondisi-kondisi operasional di dalam suatu aliran lalu lintas dan persepsi dari pengemudi dan/atau penumpang terhadap kondisi-kondisi tersebut. Kondisi-kondisi yang dimaksud adalah kecepatan dan waktu tempuh, kebebasan bermanuver, perhentian lalu lintas dan kemudahan serta kenyamanan.

Dalam MKJI (Ditjen Bina Marga 1997) tingkat pelayanan disebut juga dengan derajat kebebasan. LOS dapat diketahui dengan membandingkan volume lalu lintas terhadap kapasitas jalan, seperti Persamaan (2).

$$
\operatorname{LOS}=\frac{\mathrm{v}}{\mathrm{C}}
$$

dimana LOS adalah tingkat pelayanan, $\mathrm{V}$ adalah volume/arus lalu lintas dalam SMP/Jam, C adalah kapasitas dalam SMP/Jam.

HCM (1985) dalam (Suwardo \& Haryanto 2019) menyebutkan ada 6 tingkatan tingkat pelayanan yang dibedakan berdasarkan nilai rasio $\mathrm{V} / \mathrm{C}$, yaitu : 1) $\mathrm{V} / \mathrm{C} \leq$ 0,35 disebut $L O S$ tipe A, dengan deskripsi kondisi jalan : (a). arus lalu lintas bebas tanpa hambatan. b) volume dan kepadatan lalu lintas rendah. c) kecepatan kendaraan merupakan pilihan pengemudi. 2) $\mathrm{V} / \mathrm{C} \leq 0,54$ disebur $L O S$ tipe $\mathrm{B}$, dengan deskripsi kondisi jalan: a) arus lalu lintas stabil. b) kecepatan mulai dipengaruhi keadaan lalu lintas, tetapi dapat dipilih sesuai kehendak pengemudi. 3)
$\mathrm{V} / \mathrm{C} \leq 0,77$ disebut LOS tipe $\mathrm{C}$, dengan deskripsi kondisi jalan : a) arus lalu lintas masih stabil. b) kecepatan perjalanan dan kebebasan bergerak sudah dipengaruhi oleh besarnya volume lalu lintas sehingga pengemudi tidak dapat memilih lagi kecepatan yang diinginkannya. 4) $\mathrm{V} / \mathrm{C} \leq 0,93$ disebut $L O S$ tipe $\mathrm{D}$, dengan deskripsi kondisi jalan : a) arus lalu lintas sudah mulai tidak stabil. b) perubahan volume lalu lintas sangat mempengaruhi besarnya kecepatan perjalanan. 5) $\mathrm{V} / \mathrm{C} \leq 1,0$ disebut LOS tipe $\mathrm{E}$, dengan deskripsi kondisi jalan : a) arus lalu lintas sudah tidak stabil. b) volume kira-kira sama dengan kapasitas. c) sering terjadi kemacetan. 6) V/C > 1,0 disebut LOS tipe F, dengan deskripsi a) arus lalu lintas tertahan pada kecepatan rendah b) sering kali terjadi kemacetan. c) arus lalu lintas rendah.

\section{METODOLOGI}

Data arus lalu lintas diperoleh dengan melakukan survey berupa pencacahan kendaraan dan pejalan kaki pada periode waktu tertentu sementara geometrik jalan diperoleh melalui pengukuran secara langsung di lapangan. Sementara data-data pendukung seperti jumlah penduduk didapatkan dari studi literatur.

Selengkapnya urutan pelaksanaan penelitian dapat dilihat pada bagan alir penelitian Gambar 1

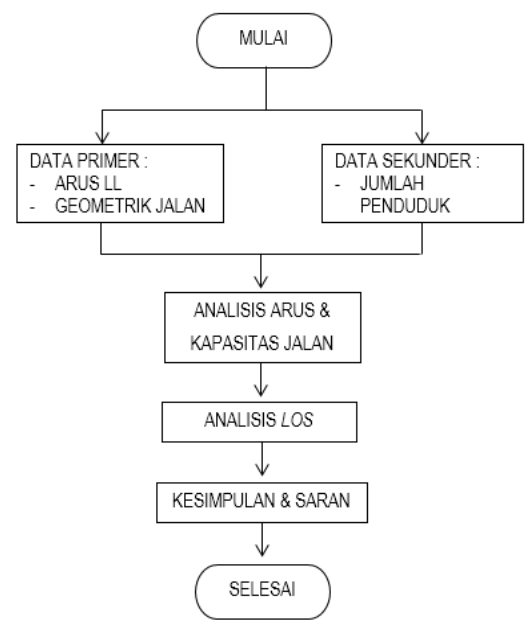

Gambar 1. Bagan Alir Penelitian 


\section{DynamicSainT}

Jilid. V No. 1., April 2020

\section{ANALISIS DAN PEMBAHASAN}

\subsection{Analisis Geometrik Jalan}

Hasil survey geometrik jalan diperoleh data sebagai berikut: a) Jalan Monginsidi, lebar lajur lalu lintas 7 meter; konfigurasi lajur $2 / 2 \mathrm{UD}$; bahu jalan $1 \mathrm{~m}$. b) Jalan Pongtiku, lebar lajur lalu lintas $8 \mathrm{~m}$; konfigurasi lajur 2/2 UD; bahu jalan 1,5 m. c) Jalan Andi Mappanyuki, lebar lajur lalu lintas $7 m+7 m$; konfigurasi lajur 4/2 D; bahu jalan $1,5 \mathrm{~m}$ (jarak ke penghalang) dan lebar kereb 1,75 m. d) Jalan Ahmad Yani, lebar lajur lalu lintas $7 m+7 m$; konfigurasi lajur 4/2 D; bahu jalan $0,5 \mathrm{~m}$ (jarak ke pengahalang) dan lebar kereb 1,5 m. e) Jalan Poros Rantepo - Bolu, lebar lajur lalu lintas $8 \mathrm{~m}$; konfigurasi lajur $2 / 2$ D; bahu jalan 1,5 m.

\subsection{Analisis Arus Lalu Lintas}

Arus atau volume lalu lintas dalam satuan SMP/jam diperoleh dengan mengalikan tiap jumlah kendaraan berdasarkan jenis dikalikan dengan nilai EMP untuk tiap jam pengamatan. Fluktuasi arus lalu lintas terhadap waktu pengamatan dapat dilihat pada Gambar 2.

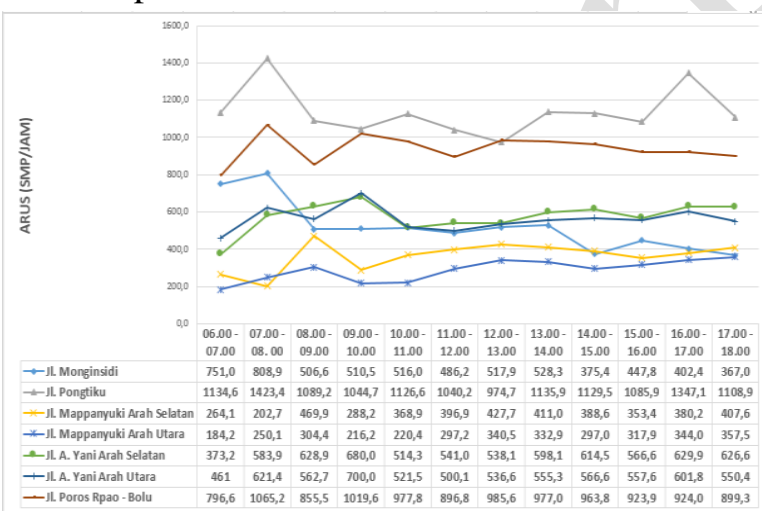

Gambar 2. Fluktuasi Arus LL terhadap Waktu Pengamatan

Dengan memperhatikan Gambar 2 dapat dijelaskan bahwa: a) Jl. Monginsidi; arus LL tertinggi sebesar 808,9 SMP pada pagi hari Pukul 07.00 - 08.00, setelah itu arus LL berangsur turun dan pada sore hari Pukul 15.00 - 18.00 arus LL sebesar 367 SMP. Pada ruas jalan ini terdapat beberapa sekolah. b) Jl. Pongtiku; arus LL tertinggi sebesar 1.423,4
SMP pada pagi hari pukul 07.00 - 08.00 lalu berangsur turun hingga 974,7 SMP pada Pukul 12.00 - 13.00. Setelah itu arus LL naik kembali sampai sebesar 1.347,1 SMP pada Pukul 16.00 - 17.00 dan kembali turun menjadi 1.108,9 SMP pada Pukul 17.00 18.00. Ruas jalan ini merupakan akses keluar masuk Kota Rantepao di sebelah selatan. c) Jl. Mappanyuki; arah lalu lintas dipisahkan oleh median jalan. Arus LL arah selatan pada pagi hari pukul $06.00-07.00$ sangat rendah yaitu sebesar 264,1 SMP dan pada pukul $07.00-08.00$ hanya 202,7 SMP. Setelah itu pukul 08.00 - 09.00 arus LL langsung naik menjadi 469,9 SMP, dan turun kembali pada pukul 09.00 - 10.00 menjadi 288,8 SMP. Arus LL berangsur naik kembali hingga siang hari pukul $12.00-13.00$ volume sebesar 427,7 SMP dan kurva arus cenderung datar hingga pada pukul 17.00 - 18.00 sebesar 407,6 SMP. Pola kurva arus LL pada arah utara hampir sama dengan arah selatan, hanya saja dengan volume LL yang sedikit lebih rendah. Pukul 06.00 - 07.00 hanya sebesar 184,2 SMP dan pada pukul 08.00 - 09.00 sebesar naik menjadi 304,4 SMP dan sejam kemudian turun kembali ke 216,2 SMP. Kemudian kurva arus L berangsur naik hingga pukul 12.00 - 13.00 sebesar 340,5 SMP. Kurva arus LL sedikit menurun pada pukul 14.00 - 15.00 yaitu 297 SMP, namun setelah itu naik kembali hingga pada sore hari pukul 17.00 - 18.00 arus LL sebesar 357,5 SMP. Jalan ini merupakan pusat pertokoan dan kuliner di Kota Rantepao. d) Jl. A. Yani; jalan ini juga merupakan jalan yang dipisahkan oleh median jalan. Pada arah selatan puncak arus LL terjadi pada Pukul 09.00 - 10.00 yaitu sebesar 680 SMP, setelah itu turun menjadi 514,3 SMP (Pukul 10.00 - 11.00). Kemudian berangsur naik kembali sampai 629,9 SMP pada Pukul 16.00 - 17.00. Pola dan volume arus LL yang hampir sama juga terjadi pada arah utara, dimana pada pukul $09.00-10.00$ sebesar 700 SMP kemudian turun ke 500,1 SMP (Pukul 11.00 - 12.00) lalu kemudian naik kembali menjadi 601 SMP pada Pukul 


\section{DynamicSainT}

Jilid. V No. 1., April 2020

16.00 - 17.00. Di Jalan Ahmad Yani terdapat pertokoan, kantor, café/restoran dan rumah sakit. e) Jl. Poros Rantepao - Bolu; arus LL tertinggi sebesar 1065, 2 SMP pada Pukul 07.00 - 08.00. Pada siang hari arus LL di ruas jalan ini cenderung stabil dikisaran 900 SMP/jam. Ruas jalan ini merupakan salah satu akses keluar masuk Kota Rantepao ke arah utara.

Sementara itu data distribusi arah arus lalu lintas masing - masing jalan selama penelitian dari pukul $06.00-18.00$ dapat dilihat pada Gambar 3.

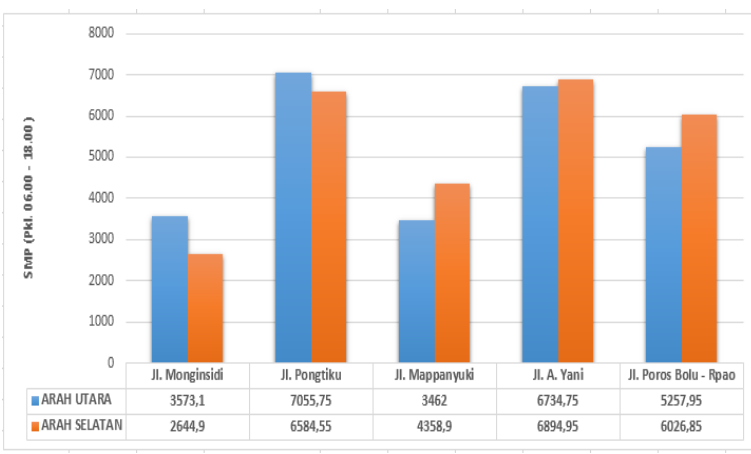

Gambar 3. Distribusi Arah Arus LL selama Masa Pengamatan

Secara prosentase distribusi arah arus LL adalah sebagai berikut: a) Jl. Monginsidi; distribusi arus LL arah utara berbanding arah selatan adalah $57 \%$ berbanding $43 \%$. b) $\mathrm{Jl}$. Pongtiku; distribusi arus LL arah utara berbanding arah selatan adalah 52\% berbanding 48\%. c) Jl. Andi Mappanyuki; distribusi arus LL arah utara berbanding arah selatan adalah $44 \%$ berbanding 56\%. d) $\mathrm{Jl}$. Ahmad Yani; distribusi arus LL arah utara berbanding arah selatan adalah 49\% berbanding $51 \%$. e) Jl. Poros Rantepao Bolu; distribusi arus LL arah utara berbanding arah selatan adalah $47 \%$ berbanding 53\%.

Pejalan kaki merupakan bagian dari lalu lintas yang wajib disurvey dalam penentuan kapasitas jalan. Data pejalan kaki dapat dilihat pada Tabel 10

Rata - rata kendaraan parkir/berhenti di sisi jalan untuk semua ruas tidak dilaksanakan survey namun dapat diasumsi kelas hambatan sampingnya rendah ( $<100 \mathrm{kend} / \mathrm{jam} / \mathrm{km})$. Demikian pula rata-rata kendaraan keluar masuk persil diasumsi rendah $\quad(<200$ kend/jam/km).

Tabel 10. Data Survey Pejalan Kaki Ruas Jalan yang Diteliti

\begin{tabular}{lcc}
\hline Ruas Jalan & $\begin{array}{c}\text { ata-rata Pejalan } \\
\text { Kaki (org/jam) }\end{array}$ & $\begin{array}{c}\text { ata-rata Pejalan } \\
\text { Kaki } \\
\text { Menyeberang } \\
\text { (org/jam/km) }\end{array}$ \\
\hline Monginsidi & 138 & 74 \\
\hline Pongtiku & 56 & 23 \\
\hline A. Mappanyuki & 154 & 86 \\
\hline A. Yani & 85 & 35 \\
\hline Poros Rpao-Bolu & 35 & 12 \\
\hline
\end{tabular}

\subsection{Analisis Kapasitas Jalan}

Dari kondisi geometrik dan konfigurasi lajur mengacu pada Tabel 4, maka diperoleh nilai kapasitas dasar masing - masing ruas jalan seperti pada Tabel 11.

Tabel 11. Kapasitas Dasar Ruas Jalan yang Diteliti

\begin{tabular}{lcl}
\hline \multicolumn{1}{c}{ Ruas Jalan } & $\begin{array}{c}\text { Kapasitas } \\
\text { Dasar }\left(\mathbf{C o}_{\mathbf{0}}\right)\end{array}$ & Ket. \\
& (SMP/Jam) & \\
\hline Monginsidi (2/2 UD) & 2.900 & Total \\
\hline Pongtiku (2/2 UD) & 2.900 & Total \\
\hline A. Mappanyuki (4/2 D) & 1.650 & er Lajur \\
\hline A. Yani (4/2 D) & 1.650 & er Lajur \\
\hline Poros Rpao-Bolu (2/2 UD) & 2.900 & Total \\
\hline
\end{tabular}

Penetuan faktor pengaruh lebar lajur mengacu pada Tabel 5, dan untuk masing masing ruas jalan diperoleh nilai seperti pada Tabel 12.

Tabel 12. Faktor Pengaruh Lebar Lajur $\left(\mathrm{FC}_{\mathrm{W}}\right)$ Ruas Jalan yang Diteliti

\begin{tabular}{lcc}
\hline \multicolumn{1}{c}{ Ruas Jalan } & FCw & Ket. \\
\hline Monginsidi (2/2 UD) & 1,00 & Total \\
\hline Pongtiku (2/2 UD) & 1,08 & Total \\
\hline A. Mappanyuki (4/2 D) & 1,00 & Per Lajur \\
\hline A. Yani (4/2 D) & 1,00 & Per Lajur \\
\hline Poros Rpao-Bolu (2/2 UD) & 1,08 & Total \\
\hline
\end{tabular}

Karena prosentase distribusi arah arus LL tidak persis sama dengan prosentase split arah pada Tabel 6, maka untuk penentuan faktor pengaruh disrtibusi arah $\left(\mathrm{FC}_{\mathrm{SP}}\right)$ diambil prosentase yang mendekati, dan diperoleh nilai seperti pada Tabel 13. 


\section{DynamicSainT}

Jilid. V No. 1., April 2020

Tabel 13. Faktor Pengaruh Distribusi Arah $\left(\mathrm{FC}_{\mathrm{SP}}\right)$ Ruas Jalan yang Diteliti

\begin{tabular}{lll}
\hline \multicolumn{1}{c}{ Ruas Jalan } & FCsP & Ket. \\
\hline Monginsidi (2/2 UD) & 0,970 & $2 / 2$ \\
\hline Pongtiku (2/2 UD) & 1,000 & $2 / 2$ \\
\hline A. Mappanyuki (4/2 D) & 0,975 & $4 / 2$ \\
\hline A. Yani (4/2 D) & 1,000 & $4 / 2$ \\
\hline Poros Rpao-Bolu (2/2 UD) & 0,970 & $2 / 2$ \\
\hline
\end{tabular}

Penentuan faktor pengaruh hambatan samping $\left(\mathrm{FC}_{\mathrm{SF}}\right)$ diawali dengan penentuan kelas hambatan dengan mengacu pada Tabel 7 dan 8. Hasilnya dapat dilihat pada Tabel 14.

Tabel 14. Kelas Hambatan Samping Ruas yang Diteliti

\begin{tabular}{|c|c|c|c|c|c|c|}
\hline \multicolumn{2}{|c|}{$\begin{array}{c}\text { Komponen Hambatan } \\
\text { Samping }\end{array}$} & \multirow[t]{2}{*}{ 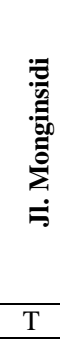 } & 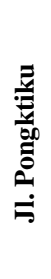 & 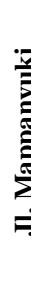 & \multirow{2}{*}{\multicolumn{2}{|c|}{ 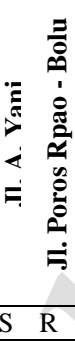 }} \\
\hline Pejalan Kaki & Kelas & & $\mathrm{R}$ & $\mathrm{S}$ & & \\
\hline & Nilai & 4 & 1 & 2 & 2 & 1 \\
\hline \multirow{2}{*}{$\begin{array}{l}\text { Pejalan Kaki } \\
\text { Menyeberang }\end{array}$} & Kelas & $\mathrm{R}$ & $\mathrm{R}$ & $\mathrm{R}$ & $\mathrm{R}$ & $\mathrm{R}$ \\
\hline & Nilai & 1 & 1 & 1 & 1 & 1 \\
\hline \multirow{2}{*}{$\begin{array}{l}\text { Kend } \\
\text { Berhenti/Parkir }\end{array}$} & Kelas & $\mathrm{R}$ & $\mathrm{R}$ & $\mathrm{R}$ & $\mathrm{R}$ & $\mathrm{R}$ \\
\hline & Nilai & 1 & 1 & 1 & 1 & 1 \\
\hline \multirow{2}{*}{$\begin{array}{l}\text { Kend Keluar } \\
\text { Masuk Persil }\end{array}$} & Kelas & $\mathrm{R}$ & $\mathrm{R}$ & $\mathrm{R}$ & $\mathrm{R}$ & $\mathrm{R}$ \\
\hline & Nilai & 1 & 1 & 1 & 1 & 1 \\
\hline Jumlah & & 7 & 4 & 5 & 5 & 4 \\
\hline
\end{tabular}

Memperhatikan jumlah nilai hambatan samping pada Tabel 14. dan dibandingkan dengan Tabel 8.c. Maka diperoleh kelas hambatan samping sebagai berikut: a) Jl. Monginsidi termasuk kelas hambatan samping sedang. b) Jl. Pongtiku termasuk kelas hambatan samping rendah. c) Jl. Mappanyuki termasuk kelas hambatan samping rendah. d) Jl. Ahmad Yani termasuk kelas hambatan samping rendah. e) Jl. Poros Rantepao - Bolu termasuk kelas hambatan samping rendah.
Analisis kemudian dilanjutkan dengan membandingkan faktor hambatan samping dengan kondisi geometrik jalan khususnya terkait bahu/kerb seperti pada Tabel 7 . Hasilnya dapat dilihat pada Tabel 15.

Tabel 15. Faktor Pengaruh Hambatan Samping $\left(\mathrm{FC}_{\mathrm{SF}}\right)$ Ruas Jalan yang Diteliti

\begin{tabular}{lllll}
\hline \multicolumn{1}{c}{ Ruas Jalan } & $\begin{array}{c}\text { Kls } \\
\text { H.S. }\end{array}$ & $\begin{array}{c}\text { Lahu/ } \\
\text { Kerb }\end{array}$ & $\begin{array}{c}\text { Jarak } \\
\text { ke } \\
\text { kerb } \\
\text { (m) }\end{array}$ & FCSF \\
\hline $\begin{array}{l}\text { Jl. Monginsidi } \\
\text { (2/2 UD) }\end{array}$ & $\mathrm{S}$ & Bahu & 1 & 0,92 \\
\hline $\begin{array}{l}\text { Jl. Pongtiku } \\
\text { (2/2 UD) }\end{array}$ & $\mathrm{R}$ & Bahu & 1,5 & 0,97 \\
\hline $\begin{array}{l}\text { Jl. A. } \\
\begin{array}{l}\text { Mappanyuki } \\
\text { (4/2 D) }\end{array}\end{array}$ & $\mathrm{R}$ & Kerb & 1,5 & 0,98 \\
\hline $\begin{array}{l}\text { Jl. A. Yani (4/2 } \\
\text { D) }\end{array}$ & $\mathrm{R}$ & Kerb & 0,5 & 0,94 \\
\hline $\begin{array}{l}\text { Jl. Poros Rpao } \\
- \text { Bolu (2/2 }\end{array}$ & $\mathrm{R}$ & Bahu & 1,5 & 0,97 \\
UD) & & & & \\
\hline
\end{tabular}

Untuk analisis terhadap faktor pengaruh ukuran ukuran kota, digunakan data jumlah penduduk. Data BPS Toraja Utara (BPS Toraja Utara 2019) menyebutkan yang menjadi pusat kota adalah Kecamatan Rantepao dengan jumlah penduduk 27.149 orang dan Kecamatan Tallunglipu dengan jumlah penduduk 19.196 orang. Dari data tersebut, dengan memperhatikan Tabel 9 maka Kota Rantepao termasuk kota sangat kecil dengan nilai $\mathrm{FC}_{\mathrm{CS}}=0,86$.

Setelah semua faktor yang berpengaruh didapatkan maka dilanjutkan dengan perhitungan kapasitas menggunakan Persamaan (1).

Perhitungan berikut adalah contoh perhitungan kapasitas untuk ruas $\mathrm{Jl}$. Monginsidi.

$\mathrm{C}=\mathrm{C}_{\mathrm{O}} \times \mathrm{F}_{\mathrm{CW}} \times \mathrm{FC}_{\mathrm{SP}} \times \mathrm{FC}_{\mathrm{SF}} \times \mathrm{FC}_{\mathrm{CS}}$

$\mathrm{C}=2.900 \times 1,0 \times 0,97 \times 0,92 \times 0,86$

$\mathrm{C}=2.225,65 \mathrm{SMP} / \mathrm{jam}$.

Selengkapnya hasil perhitungan kapasitas ruas jalan yang diteliti dapat dilihat pada Tabel 16. 


\section{DynamicSainT}

Jilid. V No. 1., April 2020

Tabel 16. Kapasitas Jalan (C)Ruas Jalan yang Diteliti

\begin{tabular}{lcccccc}
\hline \multicolumn{1}{c}{ Ruas Jalan } & $\begin{array}{c}\mathrm{C}_{\mathbf{O}} \\
(\mathrm{SMP} / \mathrm{jam})\end{array}$ & FCW & FCSP & FCSF & FCCS & $\begin{array}{c}\text { C } \\
\text { (SMP/jam) }\end{array}$ \\
\hline $\begin{array}{l}\text { Jl. Monginsidi } \\
\text { (2/2 UD) }\end{array}$ & $\mathbf{2 . 9 0 0}$ & $\mathbf{1 , 0 0}$ & $\mathbf{0 , 9 7 0}$ & $\mathbf{0 , 9 2}$ & $\mathbf{0 , 8 6}$ & $\mathbf{2 . 2 2 5 , 6 5}$ \\
\hline $\begin{array}{l}\text { Jl. Pongtiku } \\
(2 / 2 \text { UD) }\end{array}$ & $\mathbf{2 . 9 0 0}$ & $\mathbf{1 , 0 8}$ & $\mathbf{1 , 0 0 0}$ & $\mathbf{0 , 9 7}$ & $\mathbf{0 , 8 6}$ & $\mathbf{2 . 6 1 2 , 7 1}$ \\
\hline $\begin{array}{l}\text { Jl. } \\
\begin{array}{l}\text { Mappanyuki } \\
\text { (4/2 D) }\end{array}\end{array}$ & $\mathbf{1 . 6 5 0}$ & $\mathbf{1 , 0 0}$ & $\mathbf{0 , 9 7 5}$ & $\mathbf{0 , 9 8}$ & $\mathbf{0 , 8 6}$ & $\mathbf{1 . 3 5 5 , 8 5}$ \\
\hline $\begin{array}{l}\text { Jl. A. Yani } \\
\text { (4/2 D) }\end{array}$ & $\mathbf{1 . 6 5 0}$ & $\mathbf{1 , 0 0}$ & $\mathbf{1 , 0 0 0}$ & $\mathbf{0 , 9 4}$ & $\mathbf{0 , 8 6}$ & $\mathbf{1 . 3 3 3 , 8 6}$ \\
\hline $\begin{array}{l}\text { Jl. Poros Rpao } \\
\text { - Bolu (2/2 }\end{array}$ & $\mathbf{2 . 9 0 0}$ & $\mathbf{1 , 0 8}$ & $\mathbf{0 , 9 7 0}$ & $\mathbf{0 , 9 7}$ & $\mathbf{0 , 8 6}$ & $\mathbf{2 . 5 3 4 , 3 3}$ \\
\begin{tabular}{l} 
UD) \\
\hline
\end{tabular} & & & & & & \\
\hline
\end{tabular}

Pada Tabel 16 kapasitas jalan (C) untuk konfigurasi lalu lintas 2/2 UD merupakan kapasitas total jalan, sementara untuk konfigurasi 4/2 D merupakan kapasitas masing-masing lajur/arah.

\subsection{Analisis Tingkat Pelayanan Jalan}

Analisis tingkat pelayanan (LOS, level of service) dilakukan pada pada kondisi arus lalu lintas maksimum pada ruas jalan yang diteliti dengan menggunakan Persamaan (2).

Perhitungan tingkat pelayanan untuk Jl. Monginsidi pada arus LL (V) maksimum sebesar 808,9 SMP/Jam (Pukul 07.00-08.00) seperti pada Gambar 2 dibagi dengan kapasitas (C) sebesar 2.225,65 SMP/Jam yang tertera pada Tabel 16 sebagai berikut :

$$
\begin{aligned}
& L O S=\frac{\mathrm{V}}{\mathrm{C}} \\
& L O S=\frac{808,9}{2.225,65}=0,36
\end{aligned}
$$

Diperoleh rasio V/C 0,36. Dengan memperhatikan sub bab 2.5 dapat diketahui bahwa tingkat pelayanan Jl. Monginsidi pada kondisi arus maksimum adalah LOS Tipe B.

Selengkapnya hasil perhitungan rasio V/C dan tingkat pelayanan (LOS) jalan yang diteliti dapat dilihat pada Tabel 17.
Tabel 17. Tingkat Pelayanan (LOS) Ruas Jalan

\begin{tabular}{|c|c|c|c|c|c|c|}
\hline \multirow[b]{2}{*}{ Ruas Jalan } & \multicolumn{2}{|c|}{$\begin{array}{c}\text { Arus (V) } \\
\text { Maks. }\end{array}$} & \multirow{2}{*}{ 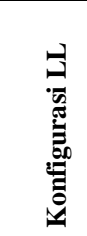 } & \multirow{2}{*}{$\begin{array}{c}\text { C } \\
\text { (SMP/ } \\
\text { Jam) }\end{array}$} & \multirow[b]{2}{*}{$\mathrm{V} / \mathrm{C}$} & \multirow[b]{2}{*}{ LOS } \\
\hline & Pukul & $\begin{array}{c}\text { (SM } \\
\text { P/ } \\
\text { Jam) }\end{array}$ & & & & \\
\hline Jl. Monginsidi & $\begin{array}{r}07.00- \\
08.00\end{array}$ & 808,9 & $2 / 2 \mathrm{UD}$ & $2.225,65$ & 0,36 & B \\
\hline Jl. Pongtiku & $\begin{array}{r}07.00- \\
08.00\end{array}$ & $1.423,4$ & $2 / 2 \mathrm{UD}$ & $2.612,71$ & 0,54 & B \\
\hline $\begin{array}{l}\text { Jl. } \\
\text { Mappanyuki } \\
\text { Arah Selatan }\end{array}$ & $\begin{array}{r}08.00- \\
09.00\end{array}$ & 469,9 & & $1.355,85$ & 0,35 & B \\
\hline $\begin{array}{l}\text { Jl. } \\
\text { Mappanyuki } \\
\text { Arah Utara }\end{array}$ & $\begin{array}{r}17.00- \\
18.00\end{array}$ & 357,5 & & $1.355,85$ & 0,26 & B \\
\hline $\begin{array}{l}\text { J1. A. Yani } \\
\text { Arah Selatan }\end{array}$ & $\begin{array}{r}09.00- \\
10.00\end{array}$ & 680,0 & & $1.333,86$ & 0,51 & B \\
\hline $\begin{array}{l}\text { Jl. A. Yani } \\
\text { Arah Utara }\end{array}$ & $\begin{array}{r}09.00- \\
10.00\end{array}$ & 700,0 & & $1.333,86$ & 0,52 & B \\
\hline $\begin{array}{l}\text { J1. Poros Rpao } \\
\text { - Bolu }\end{array}$ & $\begin{array}{r}07.00- \\
08.00\end{array}$ & 1065,2 & $2 / 2 \mathrm{UD}$ & $2.534,33$ & 0,42 & B \\
\hline
\end{tabular}
yang Diteliti

Dari Tabel 17, terlihat bahwa tingkat pelayanan (LOS) ruas jalan dalam Kota Rantepao yang diteliti saat kondisi arus maksimu masih berada dalam Tipe B. Di mana arus lalu lintas masih stabil dan kecepatan mulai dipengaruhi oleh keadaan lalu lintas namun masih tetap dapat dipilih sesuai kehendak pengemudi.

\section{KESIMPULAN DAN SARAN}

\subsection{Kesimpulan}

Kesimpulan penelitian adalah sebagai berikut : 1) Arus/volume lalu lintas maksimum Jl. Monginsidi sebesar 808,9 SMP/Jam (Pkl. 07.00-08.00); Jl. Pongtiku sebesar 1.423,4 SMP/Jam (Pkl. 07.00-08.00); Jl. Mappanyuki arah selatan sebesar 469,9 SMP/Jam (Pkl. 08.00-09.00); Jl. Mappanyuki arah utara sebesar 357,5 SMP/Jam (Pkl. 17.00-18.00); Jl. Ahmad Yani arah selatan sebesar 680 SMP/Jam (Pkl. 09.00-10.00); Jl. A. Yani arah utara sebesar $700 \mathrm{SMP} / \mathrm{Jam}$ (Pkl.09.00-10.00); sementara Jl. Poros Rantepao - Bolu arus maksimum 1.065,2 SMP/Jam pada Pukul 07.00-08.00. 2) Kapasitas ruas Jl. Monginsidi 2.225,65 SMP/Jam; Jl. Pongtiku 2.612,71 SMP/Jam; 


\section{DynamicSainT}

Jilid. V No. 1., April 2020

Jl. A. Mappanyuki $1.355,85$ per lajur; Jl. Ahmad Yani 1.333,86 SMP/Jam per lajur; Jl. Poros Rantepao - Bolu sebesar 2.534,33 SMP/Jam. 3) Tingkat pelayanan pada kondisi arus maksimum untuk semua jalan masih pada Tipe B. dengan rasio V/C Jl. Monginsidi 0,36; Jl. Pongtiku 0,54; Jl. Mappanyuki arah selatan 0,35; Jl. Mappanyuki arah utara 0,26; Jl. Ahmad Yani arah selatan 0,51; Jl. A. Yani arah utara 0,52; Jl. Poros Rantepao - Bolu 0,42 .

\subsection{Saran}

Beberapa saran untuk penelitian lanjut adalah : 1) Untuk memberikan hasil yang lebih mendekati kenyataan diperlukan hari survey dan rentang waktu pengamatan yang lebih lama. 2) Perlu dilakukan survey/pencacahan pada kendaraan parkir/berhenti serta kendaraan yang keluar dan masuk persil. 3) Perlu dilakukan analisis terhadap karakteristik lalu lintas lainnya.

\section{DAFTAR PUSTAKA}

1. BPS Toraja Utara. 2019. Statistik Daerah Kabupaten Toraja Utara. Rantepao: BPS Toraja Utara.

2. Ditjen Bina Marga. 1997. Manual Kapasitas Jalan Indonesia. Jakarta: Dirjen Bina Marga.

3. Khisty, C. Jotin \& Lall, B. Kent. 2005. Dasar-dasar Rekayasa Transportasi Jilid 1. Jakarta: Erlangga.

4. Miro, Fidel. 2012. Pengantar Sistem Transportasi. Jakarta: Erlangga.

5. Putranto, Leksmono Suryo. 2016. Rekayasa Lalu Lintas. Jakarta: indeks.

6. Rangan, Parea Rusan. 2014. "Analisa Perencanaan Bandar Udara Baru di Kabupaten Tana Toraja." Dynamic SainT 1-18. Jilid I nomor 1, http://journals.ukitoraja.ac.id/index.php/ dynamicsaint/article/view/122
7. Suwardo \& Haryanto, Iman. 2019. Perancangan Geometrik Jalan. Yogyakarta: Gadjah Mada University Press. 